Stefan MARKOVIĆ ${ }^{*}$

Universityof Belgrade, Faculty of Sport and Physical Education,

Belgrade, Serbia

Goran VUČKOVIĆ, PhD

Radivoje JANKOVIĆ, PhD

Academy of Criminalistic and Police Studies, Belgrade, Serbia

DOI: $10.5937 /$ bezbednost1901025M

UDK: 796.012.26:611.84-057.875

Originalni naučni rad

Primljen: 30. 9. 2018. godine

Revizija: 4. 12. 2018. godine

Datum prihvatanja: 15. 5. 2019. godine

\title{
Simple visual reaction time in students of Academy of Criminalistic and Police Studies**
}

Abstract: The aim of this paper is to determine gender based differences as well as the initial standard values for evaluation of simple visual reaction time in both male and female students of the Academy of Criminalistic and Police Studies (ACPS)in Belgrade. The method used in this research was laboratory testing. All datasampling was performed using the specially designed testing software that recorded reaction time with $1 \mathrm{~ms}$ precision. The variable used in this research, that is Simple Visual Reaction Time (SVRT), was calculated as a mean of 3 trials with the shortest Reaction Time from 5 correct attempts and was expressed in ms. The research sample in this study consisted of a total of 97 subjects, of which 45 females and 52 males. All subjects were third-year students of the ACPS in Belgrade. Based on the obtained results it was determined that

*stephan.markovic@hotmail.com

${ }^{* *}$ The paper is a part of the project "Effects of the Applied Physical Activity on Locomotor, Metabolic, Psychosocial and Educational Status of the Population of the Republic of Serbia", number III47015, funded by the Ministry of Education, Science and Technological Development of the Republic of Serbia Scientific Projects $2011-2018$ Cycle. 
differences in SVRT between male and female students ofthe ACPS are not statistically significant $(t=1.866, \quad p=0.066)$. Initial normative values were calculated by the application of appropriate sport metrological procedures. Presented normative models define initial qualitative standard values for 5 distinct preparedness levels as well as quantitative reference values determined for 9 characteristic percentile ranks, both for female and male students of the ACPS.

Keywords:reaction time, students, standard values, selection, evaluation

\section{Introduction}

The Academy of Criminalistic and Police Studies (ACPS) is a leading institution that educates and trains future officers of the Ministry of Interior, i.e. future ranking officers of Serbian police force(Dopsaj et al., 2011). Among other, progressive development of physical characteristics and related abilities is one of the typical goals of the study program and can be considered a precondition for efficient performance in the line of work. Evaluation of professionally important physical, physiological, cognitive and other related characteristicsis an essential part of the initial selection of candidates, as well as an integral part of Special Physical Education course that is primarily aimed at physical development of selected candidates and training in relation to specific skills required for efficient professional engagement(Blagojević et al., 2016; Milošević et al., 1995). In other words, through the synergy of selection, education, training and evaluation, the physical skills and characteristics professionally required of future police officers are developed to the desired extent(Blagojević et al., 2016; Dopsaj et al., 2012).

In their line of work,police officers can find themselves in a variety of situations that range from most simple ones like driving a patrol car, to some rare but extreme situations that include gunfire exchange (Blair et al., 2011). The common factor that highly defines how effectively many situations, including those aforementioned, will be handled and resolved is visual reaction time.Today, reaction time tasks are primarily used in psychology as a means to study mental processes and their underlying 
structures as well as the reaction process itself (Niemi \& Naatanen, 1981). The simple reaction time task, such as one used in this research, measures simple reaction time, general alertness and motor speed through the delivery of a known stimulus (audio, visual or tactile) to a known location to elicit a known response. This type of basic reaction mechanism is complemented by choice reactions that are underpinned by more complex decision making, thus requiring more time(Schmidt \& Lee, 1998).

Previous research has shownthat reaction time is affected by general factors that cannot be altered, such as age(Jevas \& Yan, 2001; Welford, 1977), intelligence(Nettelbeck, 1980) and gender (Dane \& Erzurumluoglu, 2003; Der \& Deary, 2006). More importantly, in relation to selection and training of future police officers, as well as in relation to everyday police work, it is important to point out the fact that research has generally found that practice reduces reaction time (Andoet al., 2002, 2004; Fontani et al., 2006) and is highly affected by arousal, i.e. state of attention, and fatigue(Welford, 1980). Effects of physical training on reaction time have been extensively studied but findings on the matter are somewhat inconclusive(Collardeau et al., 2001; Nakamoto \& Mori, 2008; Welford, 1980). Nevertheless, it can be argued that good physical fitness contributes to faster reaction times (Welford, 1980).

From a practical point of view, that is, in relation to the requirements of education and selection of future police officers, processes underpinning one's reactions donot have to be considered. In the line of policework, it is only necessary to produce an adequate answer within an acceptableperiod of time. One of the methods used to develop one's ability to react on a signal in the shortest possible time is the signal orientation method (Blagojević et al., 2016), which can be applied to basic and specific motor tasks and is extensively used in training of police officers. This is quite similar to the procedure used by Blair et al. (2011) to determine the reaction time of police officers in their study of reasonableness and reaction time.

Although training of one's ability to react is essential, it is always followed and complemented by control and evaluation of performance through objective scientific testing. In accordance with the previously stated, the aim of this paper is to determine 
gender based differences as well as the initial normative values for evaluation of Simple Visual Reaction Time (SVRT)in both male and female students of ACPS.

\section{Methods}

The method used in this research was laboratory testing. All data sampling was performed usingthe specially designed testing software that recorded reaction time with 1 msprecisionand was developed in Labview 2012 software surroundings.

\section{The research sample}

The research sample in this study consisted of a total of 97 subjects, of which 45 females and 52 males. All subjects were third-year students of the ACPS in Belgrade. The mean age was $22.40 \pm 1.18$ and $22.51 \pm 0.90$ years for the female and the male sample, respectively. All subjects were involved in regular physical training in accordance with the curriculumof the study program. All subjects were healthy, had good vision, and were right-handed.

\section{Measurement methods}

Before participating in this research, all subjects read and signed an informed consent form. All subjects were informed in detail about the measurement procedures and the possible risks and benefits of this research. The study was conducted in accordance with the postulates of the Declaration of Helsinki and was approved by the Ethics Committee of the University of Belgrade Faculty of Sport and Physical Education. All tests were performed in the Research Laboratory of the ACPS in Belgrade, between 9:00 and 11:30 a.m.Before the testing began, the procedure was thoroughly explained and demonstrated to all subjects, who were then further familiarized with the testing procedure and equipment by performing two trial attempts. The testing procedure consisted of 5 consecutive trials, i.e. reactions. For each trial, visual stimulus (15 cm diameter green dot appeared on a gray background) was presented on a laptop screen in the randomized time interval 
ranging between 5 and $15 \mathrm{sec}$ (Figure 1). On the appearance of a signal,the subjects had to react as quickly as possible by pressing the left mouse button with their index finger. Reaction time lower than $120 \mathrm{~ms}$ was discarded as an error(Tønnessen et al., 2013), and was substituted by an additional trial. The subjects were instructed to avoid any strenuous physical activity 12 hours prior to testing and did not perform any type of warm-up.

Figure 1.Screenshot of the software application used for the testing of SVRT

\section{Figure 1.(Page 15)}

\section{Variables}

The variable used in this research, i.e. SimpleVisual Reaction Time (SVRT), represents the latent potential of a subject to produce a maximally fast motor response to a simple visual stimulus. SVRTwas calculated as a mean of 3 trials with the shortest Reaction Time from 5 correct attempts, while the achieved result was expressed in ms.

\section{Statistical analysis}

For the purposes of this paper all raw data was subjected to descriptive statistical analysis in order to define the basic measure of central tendency (Mean), absolute and relative indicators of data dispersion, i.e. standard deviation (SD) and coefficient of variation $(\mathrm{cV} \%)$ and results span indicators - minimum and maximum (MIN, MAX). The normality of distribution of the results for the tested variable was estimated using Kolmogorov-Smirnov goodness of fit test. The difference in mean reaction time between male and female samples was determined by application of Independent samples Student's t-test. For each of the tested samples, characteristic quantitative and qualitative standard values were defined using percentile distribution and adequate sport metrological procedures (Зациорски, 1982). All data analyses 
were conducted using statistical packages Microsoft Excel 2013 and IBM SPSS v23.

\section{Results}

Table 1. Descriptive statistics for the SVRT variable in relation to gender

\begin{tabular}{c|c|c|c|c|c|c|c|c|c}
\hline \multicolumn{10}{c}{ Descriptive Statistics for the SVRT variable } \\
\hline SVRT & $\mathrm{N}$ & $\begin{array}{c}\text { Mean }(\mathrm{m} \\
\mathrm{s})\end{array}$ & $\begin{array}{c}\mathrm{SE} \mathrm{E}_{\mathrm{M}} \\
\%\end{array}$ & $\begin{array}{c}\mathrm{SD}(\mathrm{m} \\
\mathrm{s})\end{array}$ & $\begin{array}{c}\mathrm{cV} \\
\%\end{array}$ & $\begin{array}{c}\text { Min. }(\mathrm{m} \\
\mathrm{s})\end{array}$ & $\begin{array}{c}\text { Max. } \\
(\mathrm{ms})\end{array}$ & $\begin{array}{c}\text { Ske } \\
\mathrm{w} .\end{array}$ & $\begin{array}{c}\text { Kur } \\
\mathrm{t} .\end{array}$ \\
\hline $\begin{array}{c}\text { Femal } \\
\text { es }\end{array}$ & 5 & 202.30 & 1.35 & 18.89 & $\begin{array}{c}9.3 \\
4\end{array}$ & 176.00 & $\begin{array}{c}230.6 \\
7\end{array}$ & $\begin{array}{c}- \\
0.44\end{array}$ & $\begin{array}{c}- \\
0.64\end{array}$ \\
\hline Males & 5 & 196.58 & 0.71 & 10.12 & $\begin{array}{c}5.1 \\
5\end{array}$ & 180.33 & $\begin{array}{c}218.3 \\
3\end{array}$ & 0.50 & $\begin{array}{c}- \\
0.63\end{array}$ \\
\hline
\end{tabular}

Table 2. Results of the Kolmogorov-Smirnov goodness of fit test

\begin{tabular}{c|c|c|c|c|c|c}
\hline \multicolumn{6}{c}{ Kolmogorov-Smirnov test of normality } \\
\hline & \multicolumn{3}{c}{ Females } & \multicolumn{3}{c}{ Males } \\
\cline { 2 - 7 } & Statistic & df & Sig. & Statistic & df & Sig. \\
\hline SVRT & 0.124 & 45 & 0.061 & 0.107 & 52 & 0.193 \\
\hline
\end{tabular}

Table 3. Results of the Independent samples t-test for equality of means between females and males

\begin{tabular}{l|c|c|c|c|c}
\hline \multicolumn{7}{c}{ Independent Samples t-test } \\
\hline & $\mathrm{t}$ & $\mathrm{df}$ & Sig. & $\begin{array}{c}\text { Mean } \\
\text { Difference }\end{array}$ & $\begin{array}{c}\text { Std. Error } \\
\text { Difference }\end{array}$ \\
\hline SVRT & 1.866 & 70.647 & 0.066 & 5.722 & 3.067 \\
\hline
\end{tabular}

Table 4. Characteristics of the percentile distribution of the examined variable as initialquantitative reference values determined for 9 characteristic percentile ranks, for both females and males.

\begin{tabular}{c|c|c|c|c|c|c|c|c|c}
\hline \multicolumn{10}{c}{ Percentiles } \\
\hline & $\mathbf{2 . 5}$ & $\mathbf{5}$ & $\mathbf{1 0}$ & $\mathbf{2 5}$ & $\mathbf{5 0}$ & $\mathbf{7 5}$ & $\mathbf{9 0}$ & $\mathbf{9 5}$ & $\mathbf{9 7 . 5}$ \\
\hline Femal & 230. & 228. & 226. & 218. & 204. & 190. & 181. & 176. & 176. \\
es & 42 & 60 & 33 & 33 & 33 & 50 & 33 & 60 & 00 \\
\hline & 218. & 215. & 212. & 203. & 194. & 189. & 185. & 180. & 180. \\
Males & 12 & 72 & 60 & 83 & 33 & 33 & 00 & 77 & 33 \\
\hline
\end{tabular}


Table 5. Qualitative standard values for the SVRT variable in relation to gender

\begin{tabular}{c|c|c}
\hline \multicolumn{3}{|c}{ SVRT standard values } \\
\hline & Females & Males \\
\hline Excellent & $<180.49$ & $<181.39$ \\
\hline Good & $180.50-196.79$ & $181.40-191.52$ \\
\hline Average & $196.80-213.09$ & $191.53-201.64$ \\
\hline Bad & $213.10-229.39$ & $201.65-211.76$ \\
\hline Very Bad & $>229.39$ & $>211.76$ \\
\hline
\end{tabular}

Chart 1. Distribution of SVRT results in relation to gender

\section{Chart 1. (Page 15)}

\section{Discussion}

Based on the results of descriptive statistical analysis it can be argued that the coefficient of variation $(\mathrm{cV} \%)$ is at the level of $9.34 \%$ for the female sample and $5.15 \%$ for the male sample. Results of the Kolmogorov-Smirnov goodness of fit test have shown that the assumption of normality has been met for both female $(p=0.061)$ and male subsample $(p=0.193)$ (Table 2$)$. On the basis of aforementioned, it can be concluded that the obtained results are normally distributed and have an extremely high level of homogeneity(Perić, 2003), which makes them representative in terms of further scientific processing and interpretation.

Data available in scientific literature indicates that mean simple reaction time on a visual stimulus is approximately 190-200 ms(Kosinski, 2008; Milošević, 2002). This is in line with the findings of our study, where overall (males and females combined) SVRT at the level of $199.32 \pm 15.18 \mathrm{~ms}$ was determined. For the female sample, mean SVRT is at the level of $202.30 \pm 18.89 \mathrm{~ms}$, while for the male sample mean SVRT is $196.58 \pm 10.12 \mathrm{~ms}$ (Table 1). Although some formal differences in reaction time distribution (Chart 1) and mean score between males and females apparently exist, the results of the independent samples t-test have shown that 
these differences are not statistically significant $(\mathrm{t}=1.866$, $\mathrm{p}=0.066)($ Table 3$)$.

These resultsare somewhat contrary to the previous findings that indicate that females have slower reaction time comparing to males (Bleecker et al., 1987; Dane \& Erzurumluoglu, 2003; Der \& Deary, 2006)but in accordance with the apparent trend of equation of reaction time between females and males reported by Silverman (2006). The results of male ACPS students are slightly better compared to those reported in soccer players of the same age that have the average visual reaction time of $210.26 \mathrm{~ms}$ (Senel \& Eroglu, 2006). When overall reaction time of ACPS students $(199.32 \pm 15.18 \mathrm{~ms})$ is compared with the results of a study conducted by Jyothi et al. (2016), who determined simple visual reaction time of $181.5 \pm 32.13 \mathrm{~ms}$ in runners and $269.3 \pm 46.80 \mathrm{~ms}$ in physically inactive controls, differences are evident. Nevertheless, the results of previously mentioned and other studies should be considered with some heed due to different methodologies and sample characteristics.

It should be noted that, although students of the ACPS are not highly trained athletes, they are selected from the general population based on above-average physical ability criteria and can be considered highly active individuals engaged in regular physical activity within the limits of the study program requirements. The minimal selection requirementused as a cut off value in the selection of ACPS applicants is the value of $33^{\text {rd }}$ percentile of the population for all physical characteristics, while graduate students should have to score above the $66^{\text {th }}$ percentile (Blagojević et al., 2016). This fact indicates that the need for selection and training of physically capable individuals has been recognized in the professional community.

On the basis of all aforementioned, and considering the fact that reaction time measurement is an indirect index of processing capability of the central nervous system and simple means of determining sensory-motor association and performance of an individual (Das et al., 1997), the initial quantitative (Table 4) and qualitative (Table 5)SVRT normative values for ACPS students as future police personnelhave been developed. In relation to this, further studies that will include general population are necessary forthe development of definitive standard values that can be used 
in the system of selection of ACPS applicants and in the evaluation of the psychophysical status of police officers in the Republic of Serbia.

\section{Conclusion}

The aim of this paper is to determine gender-based differences as well as the initial standard values for evaluation of Simple Visual Reaction Time (SVRT) in both male and female students of Academy of Criminalistic and Police Studies (ACPS) in Belgrade. The method used in this research was laboratory testing. All data sampling was performed using the specially designed testing software that recorded reaction time with $1 \mathrm{~ms}$ precision. The variable used in this research, that is SVRT, was calculated as a mean of 3 trials with the shortest Reaction Time and was expressed in ms. The research sample in this study consisted of a total of 97 subjects, of which 45 females and 52 males. All subjects were third-year students of the ACPS in Belgrade. Based on the obtained results overall (males and females combined) SVRT at the level of $199.32 \pm 15.18 \mathrm{~ms}$ was determined. For the female sample, mean SVRT is at the level of $202.30 \pm 18.89$ $\mathrm{ms}$, while for the male sample mean SVRT is $196.58 \pm 10.12 \mathrm{~ms}$. Although some differences in reaction time between males and females apparently exist, the results of the independent samples ttest have shown that these differences are not statistically significant $(t=1.866, p=0.066)$. Given the fact that coefficient of variation $(\% \mathrm{cV})$, as a relative measure of variability of the data, indicates anextremely high level of homogeneity, and the fact that results of Kolmogorov-Smirnov goodness of fit test indicate normal distribution of the tested variable in both samples, it can be concluded that obtained results are valid for initial diagnostic use. Based on the obtained results initial normative values were calculated by the application of appropriate sport metrological procedures. Presented normative models define the initial qualitative standard values for 5 distinct preparedness levels as well as the quantitative reference values determined for 9 characteristic percentile ranks, both for female and male ACPSstudents. Taking into account the overall lack of data on reaction time in active and future police officers and the fact that 
normative values cannot be found in available scientific literature, the results of this study provide initial standard values aimed to be a basis for quantitative and qualitative assessment of students of the ACPS potential and performance from this aspect. In all, this will contribute to further improvement of the system of selection, training, and evaluation of future police officers, although further studies on general and selected population are required in order to define general and definitive standard values.

\section{Acknowledgment}

The paper is a part of the project "Effects of the Applied Physical Activity on Locomotor, Metabolic, Psychosocial and Educational Status of the Population of the Republic of Serbia", number III47015, funded by the Ministry of Education, Science and Technological Development of the Republic of Serbia Scientific Projects $2011-2018$ Cycle.

\section{References}

1. Ando, S., Kida, N., \& Oda, S. (2002). Practice effects on reaction time for peripheral and central visual fields. Perceptual and Motor Skills, 95, 747-752.

2. Ando, S., Kida, N., \& Oda, S. (2004). Retention of practice effects on simple reaction time for peripheral and central visual fields. Perceptual and Motor Skills, 98, 897-900.

3. Blagojević, M., Vučković, G., Koropanovski, N., \& Dopsaj, M. (2016). Specijalno fizičko obrazovanje 2.Beograd: Kriminalističko-policijska akademija.

4. Blair, J. P., Pollock, J., Montague, D., Nichols, T., Curnutt, J., \& Burns, D. (2011). Reasonableness and reaction time. Police Quarterly, 14(4), 323-343.

5. Bleecker, M. L., Bola-Wilson, K., Agnew, J., \& Meyers, D. A. (1987). Simple visual reaction time: Sex and age differences. Developmental Neuropsychology, 3(2), 165-172.

6. Collardeau, M., Brisswalter, J., \& Audiffren, M. (2001). Effects of a prolonged run on simple reaction time of well-trained runners. Perceptual and Motor Skills, 93(3), 679-689.

7. Dane, S., \& Erzurumluoglu, A. (2003). Sex and handedness 
differences in eye-hand visual reaction times in handball players. International Journal of Neuroscience, 113(7), 923929.

8. Das, S., Gandhi, A., \& Modal, S. (1997). Effect of premenstrual stress on audiovisual reaction time and audiogram. Indian Journal of Physiology and Pharmacology, 41, 67-70.

9. Der, G., \& Deary, I. J. (2006). Age and sex differences in reaction time in adulthood: Results from the United Kingdom health and lifestyle survey. Psychology and Aging, 21(1), 6273.

10. Dopsaj, M., Vučković, G., Milojković, B., Subošić, D., \& Eminović, F. (2012). Hand grip scaling in defining risk factors when using authorized physical force. Facta Universitatis, Series: Physical Education and Sport, 10(3), 169-181.

11. Dopsaj, M., Vučković, G., \& Vuković, M. (2011). Characteristics of isometric muscle force of back extensors with differently trained and non-trained students of the Academy of Criminalistics and Police Studies. Bezbednost, 53(3): 5-19.

12. Fontani, G., Lodi, L., Felici, A., Migliorini, S., \& Corradeschi, F. (2006). Attention in athletes of high and low experience engaged in different open skill sports. Perceptual and Motor Skills, 102, 791-816.

13. Jevas, S., \& Yan, J. H. (2001). The effect of aging on cognitive function: a preliminary quantitative review. Research Quarterly for Exercise and Sport, 72, A-49.

14. Jyothi, S., Vernekar, S. S., Manishankar, Jayalakshmi, L., Vinothkumar, \& Rashmi, R. (2016). Correlation of audio-aisual reaction time with body mass index \& skin fold thickness between runners and healthy controls. Indian Journal of Physiology and Pharmacology, 60(3), 239-246.

15. Kosinski, R. J. (2008). A literature review on reaction time. Retrieved from http://www.cognaction.org/cogs105/readings/clemson.rt.pdf

16. Milošević, M., Jovanović, S., Stojičić, R., Arlov, D., Blagojevic, M., \& Dopsaj, M. (1995). Model edukacije u specijalnom fizičkom obrazovanju. In B. Milosavljević (Ed.), Zbornik radova prvog savetovanja iz specijalnog fizičkog 
obrazovanja (pp. 9-23). Beograd: Policijska akademija.

17. Milošević, S. (2002). Percepcija, pažnja i motorna aktivnost. Beograd: Zavod za udžbenike i nastavna sredstva.

18. Nakamoto, H., \& Mori, S. (2008). Sport-specific decisionmaking in a go/no go reaction task: difference among nonathletes and baseball and basketball players. Perceptual and Motor Skills, 106(1), 163-171.

19. Nettelbeck, T. (1980). Factors affecting reaction time: Mental retardation, brain damage, and other psychopathologies. In A. T. Welford (Ed.), Reaction times (pp. 355-401). New York: Academic Press.

20. Niemi, P., \& Naatanen, R. (1981). Foreperiod and simple reaction time. Psychological Bulletin, 89(1), 133-162.

21. Perić, D. (2003). Statistika primenjena u sportu i fizičkom vaspitanju. Beograd: Fakultet Sporta i Fizičkog Vaspitanja.

22. Schmidt, R., \& Lee, T. (1998). Motor control and learning. Champaign: Human Kinetics.

23. Senel, O., \& Eroglu, H. (2006). Correlation between reaction time and speed in elite soccer players. Journal of Exercise Science and Fitness, 4(2), 126-130.

24. Silverman, I. W. (2006). Sex differences in simple visual reaction time: a historical meta-analysis (sports events). Sex Roles: A Journal of Research, 54(1-2), 57-69.

25. Tønnessen, E., Haugen, T., \& Shalfawi, S. A. I. (2013). Reaction time aspects of elite sprinters in athletic world championships. Journal of Strength and Conditioning Research, 27(4), 885-892.

26. Welford, A. T. (1977). Motor performance. In J. E. Birren \& K. W. Schaie (Eds.), Handbook of the Psychology of Aging (pp. 450-496). New York: Van Nostrand Reinhold.

27. Welford, A. T. (1980). Choice reaction times: Basic concepts. In A. T. Welford (Ed.), Reaction times (pp. 73-128). New York: Academic Press.

28. Зациорски, В. (1982). Спортивная метрлогия. Москва: Физкультура и спорт. 


\title{
Време реаговања на једноставан визуелни стимулус код студената Криминалистичко-полицијске академије
}

\begin{abstract}
Апстракт: Циљ овог рада је утврђивање разлика у времену реаговања на једноставан визуелни стимулус у функиији пола и дефинисање иницијалних нормативних вредности за потребе евалуачије истог код студената Криминалистичко-поличијске академије (КПА) у Београду. У овом истраживағу је као основни метод коришћено лабораторијеко тестирање. Узорковање података је извршено применом посебно дизајнираног софтвера који омогућава мерење времена реаговања на нивоу прецизности од 1 ms. Варијабла коришћена у овом истраживању, односно време реагована на једноставан визуелни стимулус, израчунавана је као просечна вредност 3 покушаја са најкраћим временом реакиије од 5 исправних покушаја и изражена је у $\mathrm{ms}$. Испитивани узорак се састојао од укупно 97 испитаника, од чега 45 женског и 52 мушког пола. Сви испитаници су били студенти треће године КПА у Београду. На основу добијених разултата утврђено је да разлике y времену реаговања на једноставан визуелни стимулус између студената КПА мушког и женског пола нису статистички значајне $(t=1,866, p=0,066)$. Иницијалне нормативне вредности су израчунате применом адекватних метролочких процедура у спорту. Дати нормативни модели дефинишу иницијалне квалитативне нормативне вредности за 5 карактеристичних нивоа припремљености, као и квантитативне референтне вредности утврђене за 9 карактеристичних периентилних рангова за студенте КПА мушког и женског пола.
\end{abstract}

Кључне речи: време реаговања, студенти, нормативне вредности, селекција, евалуација. 
Simple visual reaction time in students of Academy of

Criminalistic and Police Studies**

\section{Attachments}

Figure 1. Screenshot of the software application used for the testing of SVRT

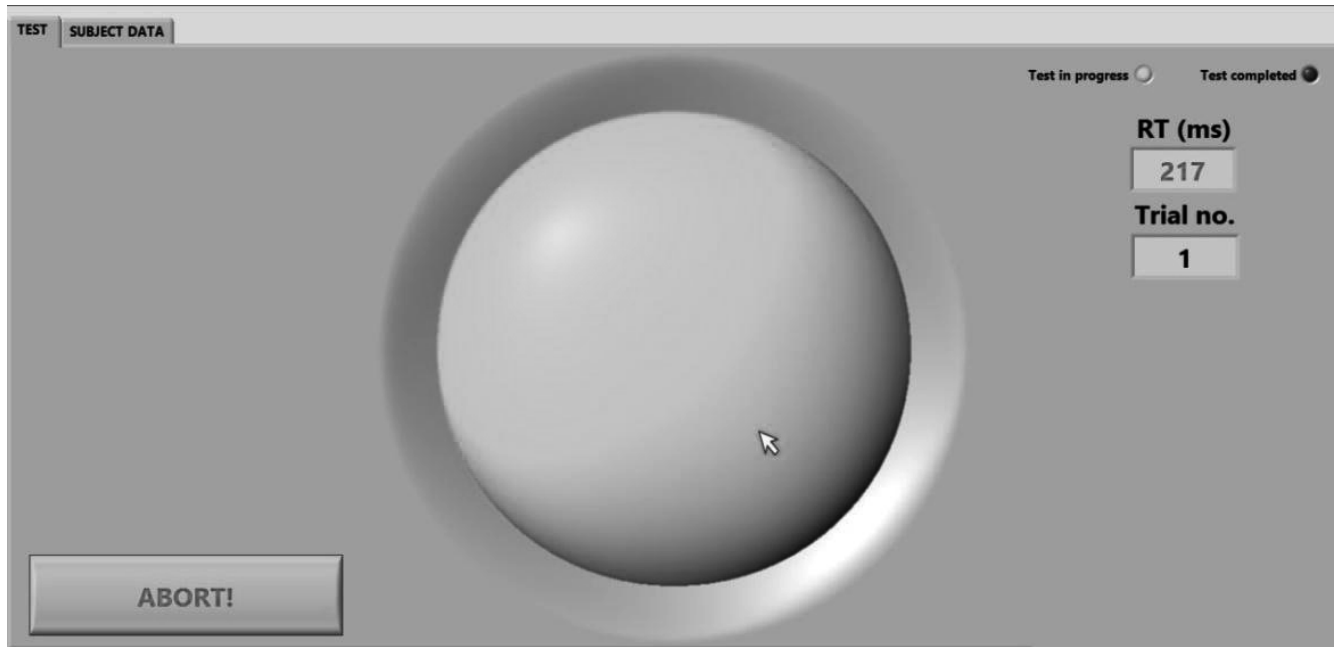


Chart1.Distribution of Simple Visual Reaction Time results in relation to gender

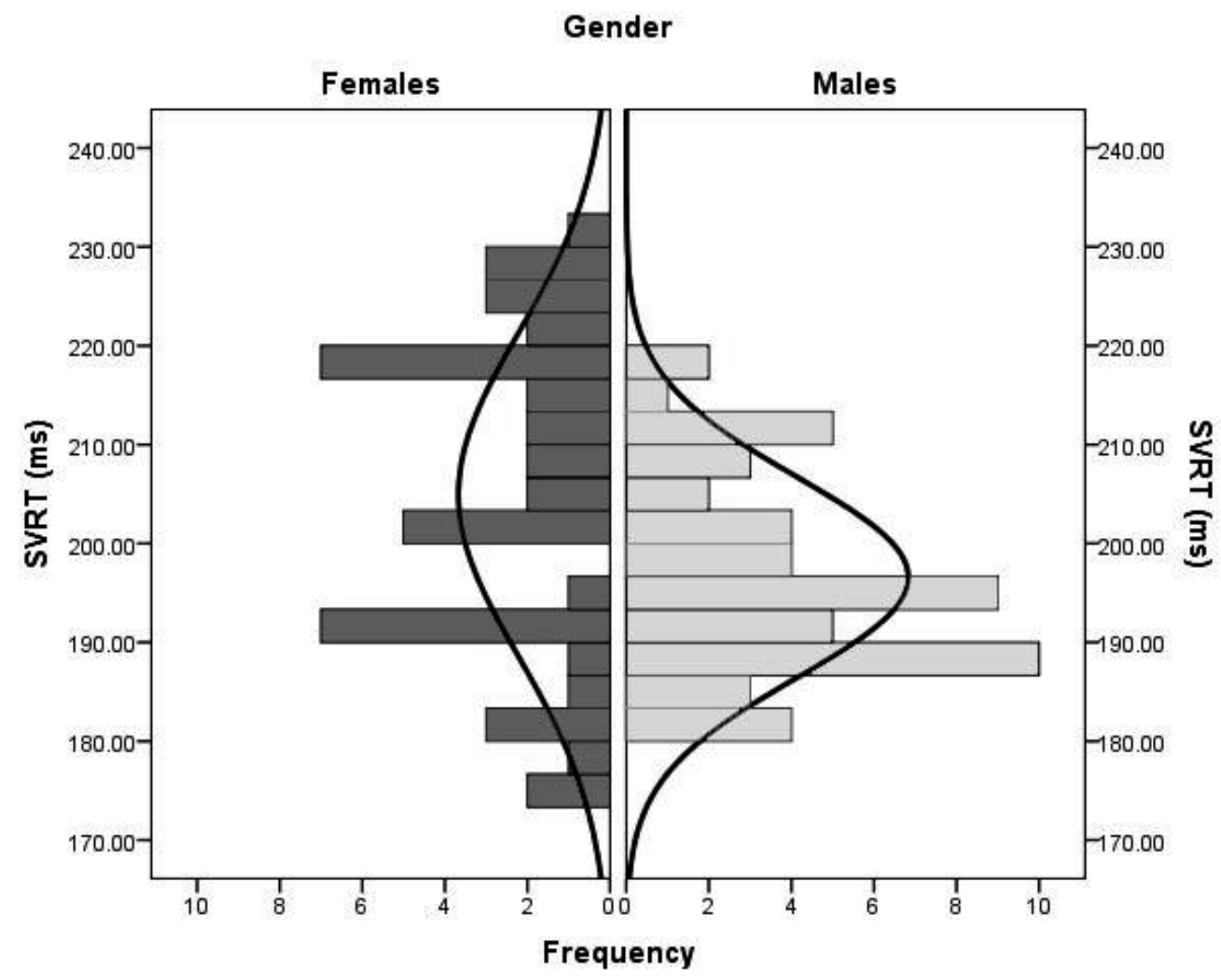

